\title{
Comparison of the Structure of CuZn40MnAl Alloy Casted into Sand and Metal Moulds
}

Pavel Kejzlar ${ }^{1}$, Jiří Machuta ${ }^{2}$, Iva Nová ${ }^{2}$

${ }^{1}$ Institute for Nanomaterials, Advanced technologies and Innovation, Technical University of Liberec, Studentska 1402/2, 46117 Liberec, Czech Republic. E-mail: pavel.kejzlar@tul.cz

${ }^{2}$ Faculty of Mechanical Engineering, Technical University of Liberec, Studentská 2, 46117 Liberec 1, Czech Republic. E-mail: jiri.machuta@tul.cz, iva.nova@tul.cz

CuZn brasses are used for manufacturing highly stressed structural comonents. Their mechanical properties as e.g. strenth, toughness or wear resistance are affected not only by their chemical composition, but also by their structure. This paper is dedicated to the study and comparison of the structure of sand- and metal mould casted $\mathrm{Cu} 40 \mathrm{Zn}$ alloy. Scanning electron microscopy supplied by energy dispersive spectroscopy and electron backscatter diffraction were used to evaluate the structure of both samples. Casting into the metal mould produces approximately five times finer grain structure compared to the sand mould. EBSD orientation mapping revealed a strong correlation between both matrix phases, $\alpha \mathrm{Cu}$ and $\beta$ ' phase. Also, the size of $\mathrm{Fe}_{2} \mathrm{MnSi}$ ternary precipitates is affected by the cooling rate.

Keywords: Brass, Structure, Casting, EBSD

\section{Acknowledgement}

The results of this project LO1201 were obtained with co-funding from the Ministry of Education, Youth and Sports as part of targeted support from the "Národní program udrăitelnosti I" programme.

\section{References}

[1] CAMPBELL, J. (2003) Casting. The new metalurgy of cast metals. Elsevier Butterworth-Heinemann, Amsterodam.

[2] CAMPBELL, J. (2004) Casting practise, The 10 rules of casting. Elsevier Science Ltd.

[3] SULAIMAN, S., HAMOUDA, A. (2004) Modelling and experimental investigation of solidification process in sand casting. In: Journal of Materials Processing Technology, Vol. 155-156, pp. 1723-1726.

[4] Magma 5.2, Software Database.

[5] MASSALSKI, T.B. (1986). Binary alloy phase diagrams, pp. 981. ASM International.

[6] MACHUTA, J., NOVÁ, I. (2014). Forma na odlitky. Číslo zápisu 36097, č. prrihlášky 2013-39576. ÚPV-ČR.

[7] KEJZLAR, P., et al. (2014). The Usage of Backscattered Electrons in Scanning Electron Microscopy. In: Manufacturing Technology, Vol. 3, pp. 333-336.

[8] KEJZLAR, P., et al. (2016). The Study of Deformation Behaviour of DC06 Deep Drawing Steel. In: Manufacturing Technology, Vol. 16, pp. 284-289.

[9] OXFORD INSTRUMENTS, NIST Structural Database. 